\title{
Sustainable Cucurbit Breeding and Production in Asia Using Public-Private Partnerships by the World Vegetable Center
}

\author{
Narinder P.S. Dhillon ${ }^{1, *}$, Suwannee Laenoi ${ }^{1}$, Supornpun Srimat ${ }^{1}$, Somchit Pruangwitayakun ${ }^{1}$, \\ Anil Mallappa ${ }^{2}$, Arvind Kapur ${ }^{3}$, Kamal K. Yadav ${ }^{4}$, Gopalkrishna Hegde ${ }^{4}$, \\ Roland Schafleitner ${ }^{5}$ (i), Pepijn Schreinemachers ${ }^{6}$ (i) and Peter Hanson ${ }^{7}$ \\ 1 World Vegetable Center, East and Southeast Asia, Kasetsart University, Kamphaeng Saen, \\ Nakhon Pathom 73140, Thailand; suwannee.laenoi@worldveg.org (S.L.); \\ supornpun.srimat@worldveg.org (S.S.); somchit.pruangwitayakun@worldveg.org (S.P.) \\ 2 Acsen HyVeg Private Limited, Plot \#20, KIADB Industrial area, Kasaba Hobli, Veerapura post, \\ Duddaballapur taluk, Bangalore 561203, India; m.anil@acsenhyveg.com \\ 3 Acsen HyVeg Private Limited, Village-Nunhera, Sohna-Ballabgarh Road, Sohna, Gurugram 122103, India; \\ arvindkapur@acsenhyveg.com \\ 4 Noble Seeds Private Limited, Yelahanka New town, Bengaluru, Karnataka 560064, India; \\ kamal@nobleseeds.org (K.K.Y.); dirresearch@nobleseeds.org (G.H.) \\ 5 World Vegetable Center, P.O. Box 42, Shanhua, Tainan 74199, Taiwan; roland.schafleitner@worldveg.org \\ 6 World Vegetable Center, East and Southeast Asia, P.O. Box 1010, Bangkok 10903, Thailand; \\ pepijn.schreinemachers@worldveg.org \\ 7 World Vegetable Center, West and Central Africa-Coastal and Humid Regions, IITA-Benin campus, \\ Cotonou, 08 BP 0932 Tri Postal, Benin; peter.hanson@worldveg.org \\ * Correspondence: narinder.dhillon@worldveg.org
}

Received: 17 June 2020; Accepted: 3 August 2020; Published: 10 August 2020

\begin{abstract}
The mission of the World Vegetable Center (WorldVeg) is research and development to realize the potential of vegetables for healthier lives and more resilient livelihoods. WorldVeg operates across Asia and Africa, and its breeding portfolio comprises global as well as traditional vegetables. Cucurbit crops make an important contribution to global food and nutrition security and are economically important to smallholder farmers in Asia, who account for $83 \%$ of global cucurbit production. The global cucurbit breeding program of WorldVeg focuses on four species: bitter gourd (Momordica charantia), tropical pumpkin (Cucurbita moschata), ridge gourd (Luffa acutangula), and sponge gourd (Luffa cylindrica syn. L. aegyptiaca). Improved cultivars have been developed by the private seed industry, however, repeated recycling of lines derived from elite hybrids has narrowed the genetic base and reduced genetic gains for yield and other key traits. This trend will continue unless a concerted effort is made to introduce new genetic variability into elite hybrids. WorldVeg has organized a breeding consortium with seed companies to facilitate access to the Center's new breeding lines derived from hitherto unexploited landraces to develop genetically diverse, improved cucurbit cultivars with enhanced yield and resistance to major diseases. Through this partnership, WorldVeg presents its improved lines and $\mathrm{F}_{1}$ hybrids at Crop Field Days for selection by private seed industry staff engaged in breeding, product development, and sales and marketing.
\end{abstract}

Keywords: Momordica charantia; Cucurbita moschata; Luffa acutangula; Luffa cylindrica; breeding; disease resistance; public-private partnership 


\section{Introduction}

"Cucurbits" is a broad term that refers to all taxa of the highly diverse family known as Cucurbitaceae, which includes at least 950 species in over 90 genera that are mainly distributed in the tropics and subtropics [1]. Key members of the family include cucumber, pumpkin, and watermelon, which are found globally as well as loofah and bitter gourd, which are more common in Asia than in other regions of the world.

Cucurbits are of enormous economic importance to smallholder farmers, particularly in Asia. The global farm gate value of cucurbits and melons was USD 94 billion in 2016 (equally split between melons and other cucurbits [2]). Asia accounted for $83 \%$ of this production, Africa 3\%, and South and Central America $2 \%$. However, many countries do not report data on cucurbits, and the true value may be higher, particularly because cucurbits are often produced in kitchen gardens for home consumption, which is not usually included in official statistics.

The public and private sectors in Asia have made major contributions to the genetic improvement of cucurbits. Public sector breeders and germplasm curators have released open-pollinated cucurbit cultivars developed through selection from landraces. Private sector breeders have developed $F_{1}$ hybrid cucurbit cultivars that have enjoyed popularity among growers because of their fruit traits as per consumer requirement, uniformity, early and high marketable yields, and in some cases, disease resistance [3]. Moreover, hybrid technology now provides better intellectual protection of products, which has created a strong incentive for seed companies to invest in $\mathrm{F}_{1}$ hybrid development programs.

Over the last two decades, gourd and pumpkin breeders have successfully developed improved cultivars with a range of fruit types that fit different market segments. To achieve quick gains and meet continuous farmer and market demands for new products, cucurbit breeders have often resorted to deriving lines by inbreeding a few elite $F_{1}$ hybrids and using this recycled germplasm to generate new hybrids. This practice has led to reduced genetic diversity among commercial cultivars of these gourds [4] and pumpkins, which has rendered these crops vulnerable to biotic and abiotic stresses and limited the potential for long-term yield improvements.

In contrast, the World Vegetable Center (WorldVeg) cucurbit breeding program has taken a different approach. Since 1971, WorldVeg has assembled a vast collection of cucurbit genetic resources in the WorldVeg genebank. The Center's cucurbit breeding program exploits the diversity of this collection to develop high yielding and disease resistant lines with a range of fruit types appropriate for different markets. Availability of whole genome reference sequences for cucurbits has opened the path for molecular breeding, making marker-assisted selection a routine process in breeding disease resistant and high yielding cucurbit cultivars [5].

WorldVeg is an international nonprofit institute for research and development that operates across Asia and Africa. WorldVeg mobilizes resources from the public and private sector to realize its mission of exploiting the potential of vegetables for healthier diets and more resilient livelihoods through greater diversity in what we grow and eat. The conservation of vegetable genetic resources and their utilization in breeding programs that deliver global public goods is an important part of the Center's work. WorldVeg's breeding programs focus on vegetables of high economic and/or nutritional importance and include global vegetables (e.g., tomato, chili and sweet pepper, onion, tropical pumpkin) as well as traditional vegetables (e.g., bitter gourd, sponge gourd, ridge gourd, amaranth, African eggplant). This paper describes the WorldVeg global cucurbit breeding program, including the history of the program, the crop species targeted, and its partnership with the public and private sectors aimed at creating impact for smallholder vegetable farmers in Asia and Africa.

\section{Background of the WorldVeg Global Cucurbit Breeding Program}

The WorldVeg global cucurbit breeding program began in 2006 at the Center's headquarters in Taiwan. The program was moved to Thailand in May 2010 and located on the Kamphaeng Saen campus of Kasetsart University in Nakhon Pathom Province, about $85 \mathrm{~km}$ northwest of Bangkok. The major goal of the WorldVeg cucurbit breeding program is to catalyze cucurbit breeding research 
in partnership with the private seed industry to facilitate discovery, piloting, and scaling up of new unique products for the benefit of everyone in the value chain including farmers, distributors, retailers, and consumers.

Current breeding efforts focus on four cucurbit species: bitter gourd (Momordica charantia), ridge gourd (Luffa acutangula), sponge gourd (Luffa cylindrica), and tropical pumpkin (Cucurbita moschata). Selection of species was based on careful consideration of a number of factors including their economic importance in targeted geographical areas, nutrient density, access to genetic resources, the improvement in the status of the crop globally, and unsolved production constraints and WorldVeg's comparative advantage in solving them versus the private sector [6]. The program does not work on globally important cucurbits such as cucumbers (slicing and pickling) and melons (watermelon and muskmelon). WorldVeg discontinued cucumber breeding because the private sector breeding investment in this crop is massive, prospects for WorldVeg to solve cucumber production problems are limited, and the nutrient content of cucumber is low relative to other vegetable crops.

The three gourd and one pumpkin species targeted for improvement are cultivated and marketed by smallholder farmers and are important crops in home gardens and community gardens throughout Asia and some parts of Africa. The estimated Asian production of gourds and pumpkins in 2017 was 16.6 million tons from 1.3 million ha, which accounted for $20.6 \%$ of total cucurbit production in Asia [2]. These cucurbitaceous vegetables provide significant dietary nutrients such as vitamins A and C, iron, potassium, and calcium [7].

WorldVeg recognized the key role of private seed companies as scaling partners for its improved lines and hybrids, and created a partnership with the private seed sector in Asia, called The Asia and Pacific Seed Association (APSA)-WorldVeg Vegetable Breeding Consortium [8]. Established in 2016, the consortium has 38 members as of 2020. Bitter gourd and tropical pumpkin are part of the consortium's current target crops while sponge gourd and ridge gourd will be added later as these programs started more recently. Members join forces by funding special projects to advance breeding efforts. Participants in these projects gain early access to the Center's unique cucurbit breeding lines, as well as useful technical information and advice.

To promote this partnership, the WorldVeg cucurbit team displays its improved cucurbit lines and $\mathrm{F}_{1}$ hybrids at the annual Crop Field Days at WorldVeg East and Southeast Asia, Research and Training Station, located on the campus of Kasetsart University in Kamphaeng Saen, Thailand. This event attracts cucurbit breeders, pathologists, product development managers, sales and marketing managers, R\&D heads, and managing directors representing various seed companies from across Asia. The WorldVeg cucurbit breeding team discusses the specific horticultural traits of WorldVeg's unique breeding lines and $\mathrm{F}_{1}$ hybrids with seed industry staff, explores methods to address the narrow genetic base of current commercial cultivars, and helps companies map a way forward to create new cucurbit market segments to meet the changing needs of growers, distributors, retailers, and consumers. The breeding strategy, output, and uptake of this public-private partnership are discussed below for each crop.

\section{Bitter Gourd}

Bitter gourd (Momordica charantia) is an important cucurbitaceous vegetable of good nutritional value. In Asia, more than 340,000 ha are devoted to its cultivation annually [9], mainly by smallholder farmers. In India alone, the bitter gourd seed market is 530-580 MT ( $\mathrm{F}_{1}$ hybrid seed $=250-280$ tons and open-pollinated (OP) seed $=280-300$ tons [10]). The crop is also cultivated in a few African countries such as Ghana, which export it to Europe where it is in high demand among Asian communities. Cultivation of this cucurbit is expanding in Zambia, Congo, and Madagascar for local consumption, and these countries export to Europe and North America [4]. Bitter gourd is also cultivated on a smaller scale in Australia (Northern Territory, Queensland, New South Wales, and Victoria), mainly using Asian cultivars for consumers of Asian origin [11]. Bitter gourd fruit contains an abundance of phytonutrients [12] and is often used in traditional medicine to manage type 2 diabetes, a disease that afflicts about 379 million people globally [13]. Clinical studies confirmed that diet supplementation with bitter gourd fruits lowers elevated fasting glucose in pre-diabetics [14,15]. 
Consumer preferences for the color, shape, skin pattern, and size of bitter gourd fruit vary between and within countries. Fruit colors range from white or cream to light green and dark green, and shapes include cylindrical, elliptical, spindle, and conical types. Fruits develop irregular longitudinal ridges and warty skin, depending on the cultivar. Nearly 28 bitter gourd fruit types are consumed in Asia (Figure 1) and these are found in eight major markets including Thailand (2 types), China (6 types), Okinawa (1 type), Vietnam ( 2 types), Taiwan (2 types), Philippine ( 2 types), and Indonesia (3 types), and in the South Asian market there are 10 types of fruit that are popular in India, Bangladesh, Pakistan, Sri Lanka, and Nepal. Asian consumers cook bitter gourd fruits with other vegetables (potato, onion, garlic), stuffed or stir-fired, or add them (the white fruit) to soups to produce a slightly bitter flavor. The fruit is also widely used for making chips, especially in southern India. Bitter gourd tea prepared from dried fruits is a popular health drink in Japan and some other Asian countries.
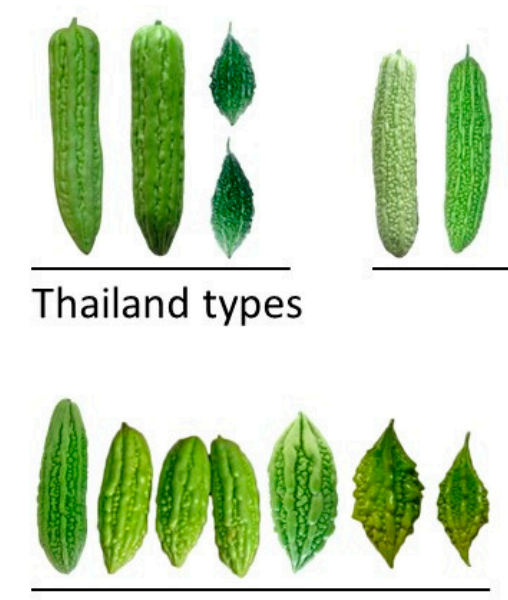

Vietnam types

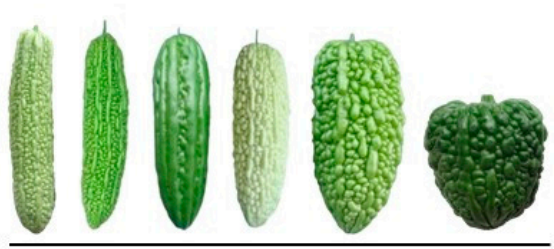

China types



Taiwan types

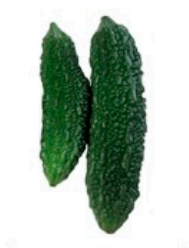

Okinawa type

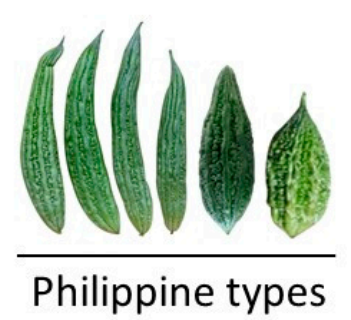

Philippine types
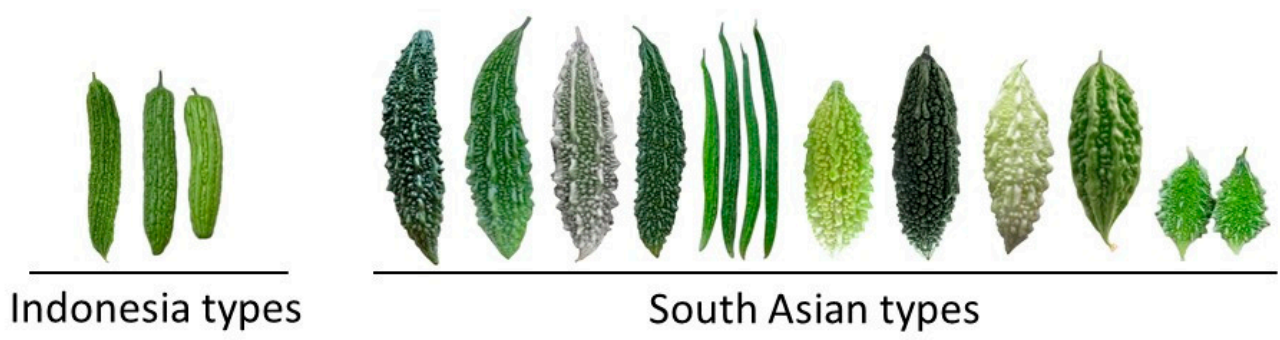

South Asian types

Figure 1. Various market segments for bitter gourd based on fruit color, shape, and skin pattern.

Bitter gourd cultivars, Jade Star and Vivek were the first $F_{1}$ hybrids released in the early 1980s in the Philippines and India by East-West Seed and Mahyco, respectively, and this breakthrough transformed bitter gourd in Asia from a semi-commercial crop into a major commercial crop. More seed companies initiated bitter gourd breeding programs, often using a small number of closely related bitter gourd lines in commercial breeding and focusing primarily on elite $\times$ elite crosses to capitalize on previous breeding successes. This resulted in a narrowing of the genetic diversity within the bitter gourd crop.

Systematic and comprehensive evaluation of the WorldVeg global collection of landraces helped to develop $>400$ bitter gourd breeding lines through inbreeding of selected genebank accessions (heterogeneous and heterozygous landraces) originating from different Asian countries, and subsequent selection within and among progeny rows. These lines exhibited improved yield and enhanced fruit quality in trials conducted at WorldVeg in Thailand and at other locations. Genetic analysis of a subset of these lines using molecular markers identified three subpopulations that largely reflect the geographic origin of the material [4].

Cucurbit powdery mildew (CPM) caused by Podosphaera xanthii $(P x)$ is a serious fungal foliar disease which affects cucurbit production in open fields and greenhouses. Disease outbreaks result 
in a rapid loss of the foliar photosynthetic area, leading to premature foliage loss, reduction in plant growth, and subsequent reduction in fruit yield and quality [16]. Multi-location tests by WorldVeg and five private seed companies revealed the presence of four unique $P x$ races in bitter gourd in different Asian countries. WorldVeg released five CPM resistant bitter gourd lines in 2018 [17], and subsequently it was determined that resistance in these lines is controlled by two independent, recessive genes [18]. WorldVeg has developed 28 additional CPM resistant bitter gourd lines from different market segments derived from landraces through inbreeding and selection (Table 1). Breeders of seed companies associated with WorldVeg through the APSA-WorldVeg Vegetable Breeding Consortium are transferring CPM resistance from these sources into their elite lines from different market segments [19].

Table 1. Cucurbit powdery mildew (CPM)(caused by Podosphaera xanthii) disease severity scored 12 days after the third artificial inoculation, measured using 28 bitter gourd breeding lines and the CPM susceptibility check (AVBG1331) and CPM resistance check (AVBG1330) and grown in the net-house at Kamphaeng Saen, Thailand, December 2019-January 2020.

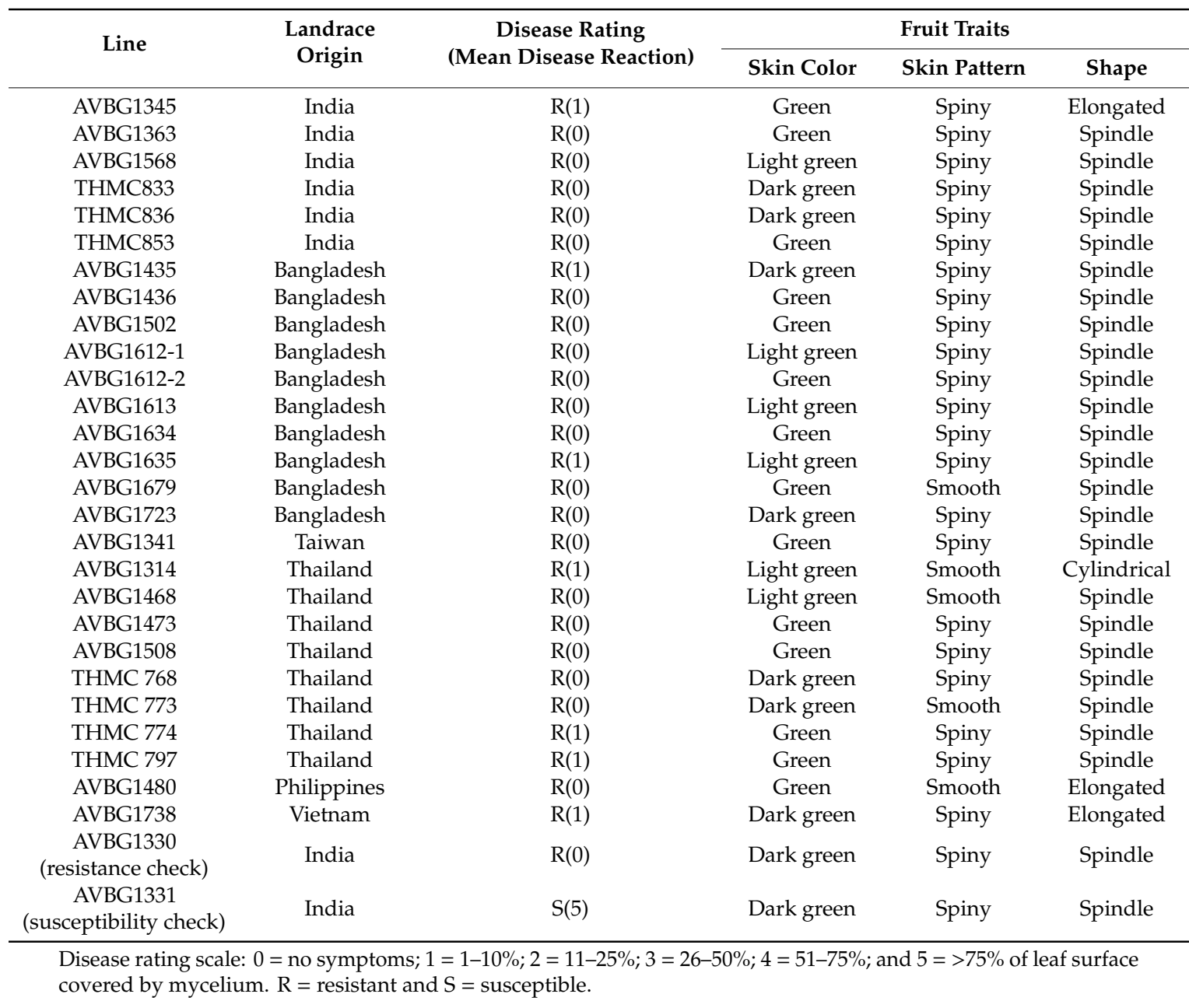

Tomato leaf curl New Delhi virus (ToLCNDV) (genus Begomovirus, family Geminiviridae) is an economically significant bipartite begomovirus that can cause severe epidemics in bitter gourd in South Asia [20]. Bitter gourd lines that are resistant to ToLCNDV are not available, thus this begomovirus is a major constraint to bitter gourd production in Asia. Severe ToLCNDV infection leads to short internodes and distorted, upward-curling, often chlorotic leaves. The virus is transmitted by the whitefly Bemisia tabaci Genn. in a persistent manner [21]. WorldVeg-developed bitter gourd line AVBG1655 (derived from a Bangladeshi landrace) was consistently rated resistant to ToLCNDV in multi-location trials in India conducted by private seed companies [22], and this could be used 
as a potential stock to introgress ToLCNDV resistance into locally adapted bitter gourd cultivars. Noble Seeds Private Limited India (Bangalore, India) recently developed two bitter gourd hybrids (NBL 368, NBTH 19156) resistant to ToLCNDV using this resistance source, and these are undergoing multi-location testing in India [23]. Currently, WorldVeg bitter gourd breeding partners with 25 seed companies, all of which are using AVBG1655 to transfer ToLCNDV resistance into their breeding lines. In the meantime, WorldVeg is seeking new sources of begomovirus resistance.

Average yields of commercial OP bitter gourd cultivars range from 12 to $15 \mathrm{t} \mathrm{ha}^{-1}$, whereas commercial hybrids yield from 25 to $30 \mathrm{t} \mathrm{ha}^{-1}$ [24]. Due to the narrow genetic base of seed company breeding material, it has been difficult to break through the yield plateau for commercial $\mathrm{F}_{1}$ hybrids. The WorldVeg bitter gourd line AVBG1325 (derived from a landrace) is a predominantly gynoecious line with good combining ability. WorldVeg made a marked breakthrough with an $\mathrm{F}_{1}$ bitter gourd hybrid (AVBG1601) using its own developed inbred lines (AVBG1325 and CPM resistant line AVBG1334), and this $\mathrm{F}_{1}$ hybrid achieved yields of $36-50 \mathrm{t} \mathrm{ha}^{-1}$ in multi-location trials conducted by public sector breeders in Thailand and Myanmar and by Noble Seeds Private Limited in India (Table 2). Three seed companies have released this $\mathrm{F}_{1}$ hybrid in India under different brand names including Figo, Asha, and KBIH $25[10,23,25]$. AVBG1325 has been found to combine marketable yield and earliness by almost all seed companies in the project. WorldVeg bitter gourd lines have also been used by several companies to develop improved bitter gourd $\mathrm{F}_{1}$ hybrids including Sakata Seeds India Private Limited, Gurugram, India (Leena, Sakata 7159) [26], Ajeet Seeds Private Limited, Aurangabad, India (Green Wonder, Treasure) [27], and Kaveri Seeds Private Limited, Secundrabad, India (Chhote Lal, Barhe Lal) [28]. Bitter gourd hybrids developed by other collaborative seed companies are in advanced stages of multi-location testing in India [29].

Table 2. Fruit yield ( $\mathrm{t} \mathrm{ha}^{-1}$ ) of WorldVeg bitter gourd $\mathrm{F}_{1}$ hybrid AVBG1601 and local checks evaluated in four locations across Southeast and South Asia.

\begin{tabular}{cccccc}
\hline \multirow{2}{*}{ Cultivar } & \multicolumn{4}{c}{ Location } \\
\cline { 2 - 6 } & $\begin{array}{c}\text { Kamphaeng Saen, } \\
\text { Thailand }\end{array}$ & $\begin{array}{c}\text { Nay Pyi Taw, } \\
\text { Myanmar }\end{array}$ & $\begin{array}{c}\text { Bangalore, } \\
\text { India }\end{array}$ & $\begin{array}{c}\text { Sonepat, } \\
\text { India }\end{array}$ & $\begin{array}{c}\text { Guntur, } \\
\text { India }\end{array}$ \\
\hline AVBG1601 & 39.6 & 43.9 & 50.9 & 43.4 & 36.2 \\
Arjuna (Check) & 26.9 & - & - & - & - \\
Perfect 212 (Check) & - & 31.9 & - & - & - \\
Amanshri (Check) & - & - & 43.5 & 32.0 & 23.8 \\
VNR 22 (Check) & - & - & 34.4 & 30.2 & 24.1 \\
CV\% & 23.8 & 11.2 & 9 & 7.9 & 10.9 \\
LSD (0.05) & 5.9 & 5.9 & 7.3 & 5.1 & 5.8 \\
\hline
\end{tabular}

A bitter gourd recurrent selection program was initiated at WorldVeg in 2011. The base population was created by intercrossing diverse genebank accessions and commercial hybrids that possess important horticultural traits such as high fruit yield, fruit glossiness, uniform green fruit without white tips and narrow necks, early bearing, long fruit duration, and resistance to CPM and begomovirus. Pedigree selection followed four cycles of recurrent selection. Bitter gourd lines developed from this program are now being tested in preliminary yield trials. These lines have many key traits such as blunt, strong fruit spines (a trait desired by distributors), uniform glossy green fruit color, absence of white tips and narrow neck (traits that are preferred by consumers), improved early and total yield, and resistance to CPM and begomovirus (traits favored by growers). These improved lines will be offered to partner seed companies for assessment and selection.

\section{Pumpkin}

Tropical pumpkin (Cucurbita moschata) is a widely grown cucurbit of great economic and nutritional importance. Pumpkin is eaten boiled, steamed, or roasted or used to make soups and purees. Leaves are also used as a cooked vegetable or in soups. In India alone, the pumpkin seed market is $335 \mathrm{MT}$ 
$\left(F_{1}\right.$ hybrid seed $=85$ tons and OP seed $=250$ tons; $\left.[10,24,29,30]\right)$. In Bangladesh, pumpkin ranks next to eggplant (brinjal) and radish in area under cultivation (9600 ha) [31]. Pumpkin is also used as a rootstock to manage soil-borne diseases in melons [9]. Pumpkin is a rich source of micronutrients, especially bioavailable provitamin A carotenoids, tocopherol, and ascorbic acid, which have major roles in human nutrition as vitamin $\mathrm{E}$ and vitamin $\mathrm{C}$. It is also a source of minerals such as calcium, potassium, and iron [7]. The World Health Organization classifies vitamin A deficiency (VAD) as a public health problem with high prevalence in Sub-Saharan Africa (48\%) and South Asia (44\%) [32]. Pumpkin lines developed by WorldVeg are rich in $\beta$-carotene (provitamin A) with contents up to $6.01 \mathrm{mg} / 100 \mathrm{~g}$ (fresh fruit weight basis), as bioassayed by the Highland Research and Development Institute (HRDI), Thailand [33]. Eating $100 \mathrm{~g}$ of pumpkin can therefore easily provide the minimum daily requirement of $4.8 \mathrm{mg} \beta$-carotene (800 micrograms of vitamin $\mathrm{A}$ ).

Multiple viruses such as the cucumber mosaic virus (CMV), papaya ringspot virus (PRSV-W), zucchini yellow mosaic virus (ZYMV), squash leaf curl virus (SLCV), ToLCNDV, cucurbit aphid borne yellow virus (CABYV), and polerovirus are serious constraints to pumpkin production in the tropics of Asia and Africa and are capable of causing yield losses up to $100 \%$. Moreover, there are worldwide reports of mixed virus infections in cucurbits [20,34-36]. There are no commercial tropical pumpkin open-pollinated cultivars or $\mathrm{F}_{1}$ hybrids that are resistant to a broad spectrum of viruses. Furthermore, commercial pumpkin seed markets in Asia and Africa are based on a few $\mathrm{F}_{1}$ hybrids/OP cultivars with limited prospects for long-term yield improvements unless additional genetic diversity is introduced for breeding. The WorldVeg global tropical pumpkin breeding program is based at Kasetsart University, Kamphaeng Saen campus, Thailand, a location where potyviruses (ZYMV, PRSV-W) and begomoviruses (SLCV, ToLCNDV) are endemic and have been confirmed through PCR and ELISA tests of virus symptomatic leaves sampled from pumpkin field trials conducted since 2012 [37]. This endemic multiple virus pressure provides WorldVeg pumpkin breeding with the opportunity to select for virus resistance.

In 2010, WorldVeg began to tap the diverse tropical pumpkin germplasm stored in its genebank. Over 800 accessions originating from 26 countries in Asia, Africa, and South America were evaluated in fields infested with multiple viruses in Kamphaeng Saen, Thailand. Initial success in identifying promising accessions with virus tolerance encouraged WorldVeg to launch the pumpkin breeding program. Populations were segregated for virus resistance, CPM resistance, and fruit traits such as skin color (mottled green, black-green, light green), shape (flat round, oval, round, long), and flesh color (yellow, light yellow, dark yellow, orange, light orange, dark orange). Virus and CPM tolerant plants with desirable fruit qualities were selected within and between accessions and populations, and hand pollinated (controlled pollination) to produce progeny for the next season of selection (plant to progeny row). Pedigree selection led to the identification of more than 150 virus tolerant lines that possessed improved fruit quality from different market segments (Table 3, Figure 2). Forty-nine pumpkin lines were tolerant to both viruses and CPM. These lines were showcased to 51 participants from 22 seed companies attending the Pumpkin Open Field Day on 22 January 2020. WorldVeg has developed a three-year bilateral pumpkin breeding project with private seed companies to share the outputs of this project.

The aphid-transmitted ZYMV is a major pathogen of pumpkin in Taiwan. We found that the C. moschata landrace, "Nigerian Local" is resistant to the most virulent strain, ZYMV-TN3, which is prevalent in Taiwan. Resistance is controlled by two complementary dominant genes [38]. WorldVeg released the ZYMV-TN3 resistant OP pumpkin cultivar, "Hualien AVRDC No. 1-Taisun" and the ZYMV-TN3 resistant $F_{1}$ hybrid, Hualien "AVRDC No. 2-Hope", and these cultivars were licensed (non-exclusively) by the Council of Agriculture (COA) Taiwan to SING-FLOW Seed Trading Company Limited, Tainan, Taiwan in 2018 and to Evergrow Seed Company Limited, Tainan, Taiwan in 2019 [39]. 
Table 3. Pumpkin lines of different market segments tolerant to multiple viruses developed from diverse germplasm accessions evaluated at the World Vegetable Center East and Southeast Asia, Thailand.

\begin{tabular}{|c|c|c|c|}
\hline $\begin{array}{l}\text { No. Inbred Lines } \\
\text { Tolerant to Multiple } \\
\text { Viruses in the Field }\end{array}$ & Landrace Origin & Fruit Shape & Fruit Skin Color \\
\hline 3 & Vietnam & Flat round & Dark green \\
\hline 4 & Vietnam & Flat round & Mottled green \\
\hline 4 & Vietnam & Butternut & Mottled green \\
\hline 2 & Vietnam & Butternut & Dark green \\
\hline 1 & Vietnam & Long & Mottled green \\
\hline 1 & Korea & Globular & Dark green \\
\hline 3 & Korea & Globular & Mottled green \\
\hline 1 & Korea & Oblong & Mottled green \\
\hline 1 & Korea & Flat round & Dark green \\
\hline 2 & Korea & Flat round & Mottled green \\
\hline 2 & Korea & Heart & Mottled green \\
\hline 6 & Myanmar & Flat round & Dark green \\
\hline 8 & Myanmar & Flat round & Mottled green \\
\hline 3 & Myanmar & Globular & Mottled green \\
\hline 33 & Thailand & Flat round & Dark green \\
\hline 7 & Thailand & Flat round & Mottled green \\
\hline 1 & Thailand & Flat round & Green \\
\hline 3 & Thailand & Globular & Dark green \\
\hline 2 & Thailand & Butternut & Dark green \\
\hline 1 & Thailand & Butternut & Mottled green \\
\hline 1 & Thailand & Long & Dark green \\
\hline 3 & Taiwan & Long & Mottled green \\
\hline 2 & Taiwan & Butternut & Mottled green \\
\hline 2 & Taiwan & Globular & Dark green \\
\hline 2 & Taiwan & Globular & Mottled green \\
\hline 1 & Taiwan & Oblong & Mottled green \\
\hline 2 & China & Butternut & Mottled green \\
\hline 1 & China & Long & Mottled green \\
\hline 4 & India & Oblong & Dark green \\
\hline 11 & India & Oblong & Mottled green \\
\hline 2 & India & Oblong & Mottled dark green \\
\hline 2 & India & Oblong & Green \\
\hline 20 & India & Flat round & Mottled green \\
\hline 2 & India & Globular & Mottled green \\
\hline 1 & India & Long & Dark green \\
\hline 8 & Bangladesh & Globular & Dark green \\
\hline 5 & Bangladesh & Globular & Mottled green \\
\hline 5 & Bangladesh & Globular & Green \\
\hline 27 & Bangladesh & Flat round & Dark green \\
\hline 6 & Bangladesh & Flat round & Mottled green \\
\hline 2 & Bangladesh & Flat round & Green \\
\hline 2 & Bangladesh & Oblong & Dark green \\
\hline 3 & Bangladesh & Oblong & Mottled green \\
\hline 1 & Bangladesh & Oblong & Green \\
\hline 1 & Bangladesh & Heart & Dark green \\
\hline 1 & Bangladesh & Long & Dark green \\
\hline 1 & Cambodia & Butternut & Dark green \\
\hline 1 & USA & Globular & Mottled green \\
\hline 1 & USA & Flat round & Mottled green \\
\hline
\end{tabular}



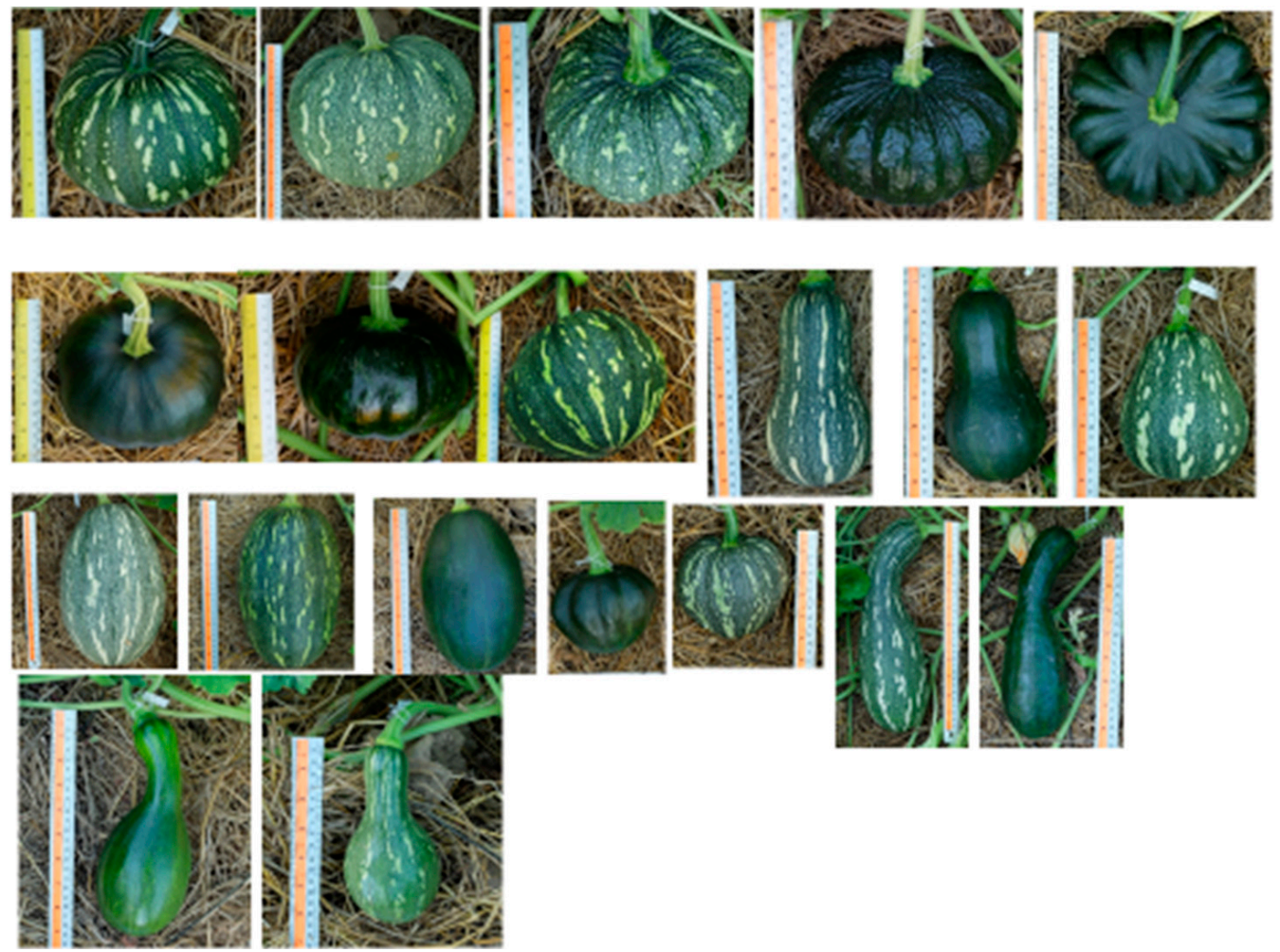

Figure 2. Fruit color and shape variability among pumpkin breeding lines developed at WorldVeg.

\section{Loofah}

Sponge gourd (Luffa cylindrica; syn. L. aegyptiaca) and ridge gourd (L. acutangula) are two cultivated species of the genus Luffa. Loofah fruit provides calcium $(20 \mathrm{mg} / 100 \mathrm{~g}$ fresh weight (FW), magnesium (14 mg/100 g FW), potassium (139 mg/100 g FW), and vitamin A (410 IU) for human nutrition [7]. A $200 \mathrm{~g}$ serving covers between $5 \%$ and $16 \%$ of the daily recommended intake of the above nutrients. Immature loofah fruit have an important role in Asian and African cuisines and are eaten as vegetables, boiled, peeled or fried, and are used in curries. Loofah can be grown during the hot and wet season and has excellent shipping and storage properties. The fibrous endocarp of mature fruits (the loofah scrubbing sponge) is popular with consumers in the USA, Japan, and Asia. The Indo-Burma region and India (including Bangladesh) are considered the primary centers of diversity of sponge gourd and ridge gourd, respectively [40]. These nutritious gourds are an important source of livelihood for smallholder farmers in Asia and can be grown in various agro-climates. Great variability of fruit size, shape, and color can be observed in both species. There are two market segments of sponge gourd: light green and green to dark green fruit color. Three market segments for ridge gourd are recognized and these are based on fruit length: small, medium, and long. These gourds rank high in the cucurbit portfolio of seed companies. In India alone, the total loofah seed market is $490 \mathrm{MT}$ (ridge gourd: $\mathrm{F}_{1}$ hybrid seed $=$ 80 tons, $\mathrm{OP}=80$ tons; sponge gourd: $\mathrm{F}_{1}$ hybrid seed $=200$ tons, $\mathrm{OP}=130$ tons $\left.[10,23,24]\right)$. The ridge gourd and sponge gourd seed market in Bangladesh is 16 and 22 MT, respectively [41]. Most loofah breeding research is concentrated in India, and a recent survey of APSA member companies indicated that loofah should be considered a priority crop for breeding research by WorldVeg as moderate to strong growth is expected in the size of the seed market in the next 10 years [42].

Current commercial loofah cultivars are susceptible to ToLCNDV, and controlling this disease is a major challenge for loofah growers. From an economic perspective, downy mildew (DM) caused by Pseudoperonospora cubensis is the second most important fungal foliar disease of loofah. OP cultivars derived from landraces are being rapidly replaced by modern $\mathrm{F}_{1}$ hybrids; however, the genetic base has narrowed because of breeder's over-reliance on the use of a few elite $F_{1}$ hybrids to derive inbred lines for hybrid development. Loofah genetic resources (from different market segments) that are 
resistant to ToLCNDV are not available, and the diversity of loofah germplasm held by seed companies is extremely limited.

Both ToLCNDV and DM are endemic at WorldVeg's research station at Kamphaeng Saen, Thailand. We screened 467 genebank accessions of ridge gourd and 783 accessions of sponge gourd against ToLCNDV and DM for two growing seasons per year from 2016 to 2019at our station in Kamphaeng Saen. Populations were segregated for resistance to ToLCNDV and DM, and fruit traits such as color, shape, length, bitterness, and duration of fruit harvest. Plants tolerant to ToLCNDV and DM belonging to different market segments (non-bitter fruit) were selected and hand-pollinated (controlled pollination) to create progeny for the next season of selection (plant to progeny row). Pedigree selection led to the development of 82 ridge gourd and 65 sponge gourd lines resistant to ToLCNDV (Tables 4 and 5) and out of these lines, nine ridge gourd and 23 sponge gourd lines are tolerant to DM [43]. These lines cover all the market segments of loofah (Figures 3 and 4). The white-seeded sponge gourd seed market is 40-50 MT in India, where the seed market is completely dominated by the white-seeded cultivar (light green fruit) of Century Seeds Private Seed Limited, Delhi, India (acquired by HM Clause). WorldVeg has developed twenty diverse white-seeded sponge gourd lines with resistance to ToLCNDV and tolerance to DM, which will help in the development of better white-seeded cultivars and thus broaden the genetic base of this specific market segment product. These elite loofah lines will be tested against ToLCNDV and DM in multi-location trials in Asia in partnership with the seed companies, and seed industry breeders can exploit this new genetic variability to develop better genetically broad-based hybrids for commercial exploitation.

Table 4. Ridge gourd lines (82) of different market segments tolerant to the tomato leaf curl New Delhi virus (ToLCNDV), developed from diverse germplasm at the World Vegetable Center.

\begin{tabular}{ccc}
\hline $\begin{array}{c}\text { No. Inbred Lines } \\
\text { Tolerant to ToLCNDV }\end{array}$ & Landrace Origin & $\begin{array}{c}\text { Market Segment Based on Fruit } \\
\text { Length at Marketable Stage }\end{array}$ \\
\hline 39 & Bangladesh & Short \\
21 & Bangladesh & Medium \\
3 & Bangladesh & Long \\
8 & Thailand & Short \\
8 & Thailand & Medium \\
2 & Thailand & Long \\
1 & Philippines & Medium \\
\hline \multicolumn{2}{l}{ Market segments: short $(25-30 \mathrm{~cm})$, medium $(31-44 \mathrm{~cm})$, long $(45-55 \mathrm{~cm})}$.
\end{tabular}

Table 5. Sponge gourd lines (65) of different market segments tolerant to ToLCNDV, developed at World Vegetable Center.

\begin{tabular}{ccc}
\hline $\begin{array}{c}\text { No. Inbred Lines } \\
\text { Tolerant to ToLCNDV }\end{array}$ & Landrace Origin & $\begin{array}{c}\text { Market Segment } \\
\text { Based on Fruit Color }\end{array}$ \\
\hline 16 & Bangladesh & Green \\
22 & Bangladesh & Light green \\
14 & Bangladesh & Dark green \\
5 & Thailand & Green \\
1 & Thailand & Light green \\
2 & Thailand & Dark green \\
3 & Vietnam & Green \\
1 & Cambodia & Green \\
1 & Indonesia & Green \\
\hline
\end{tabular}




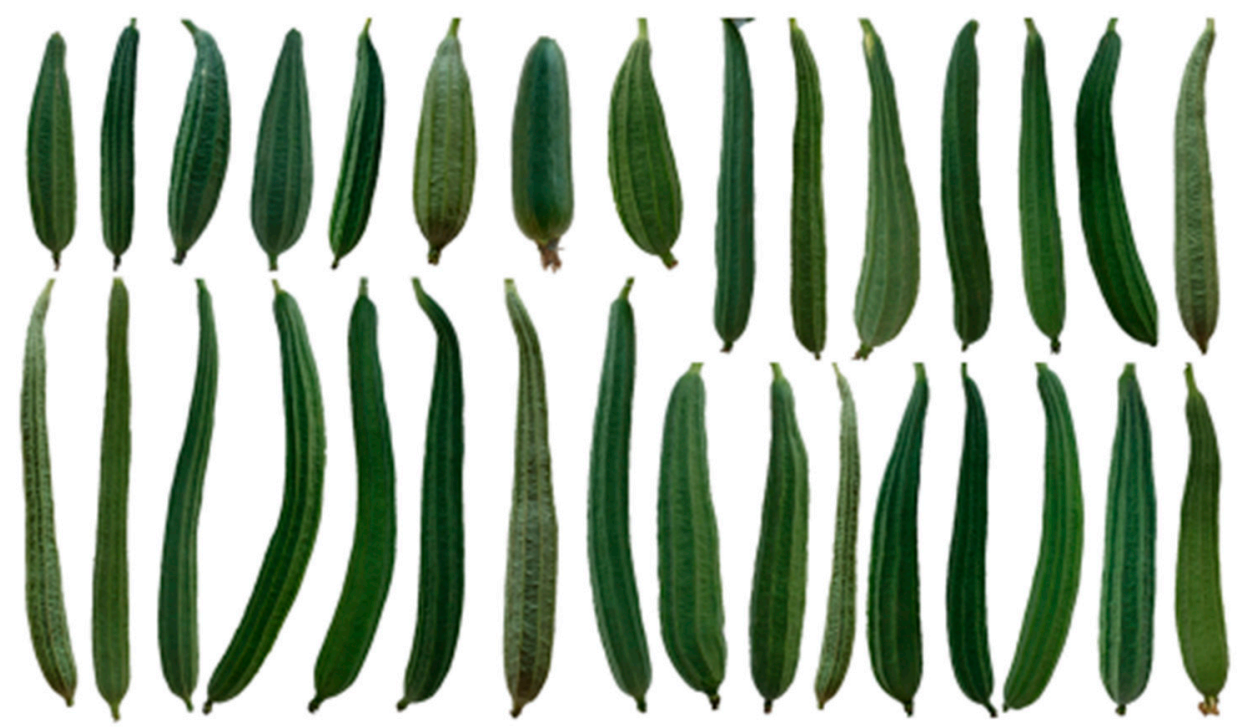

Figure 3. Fruit color and length variability among ridge gourd breeding lines developed at WorldVeg.

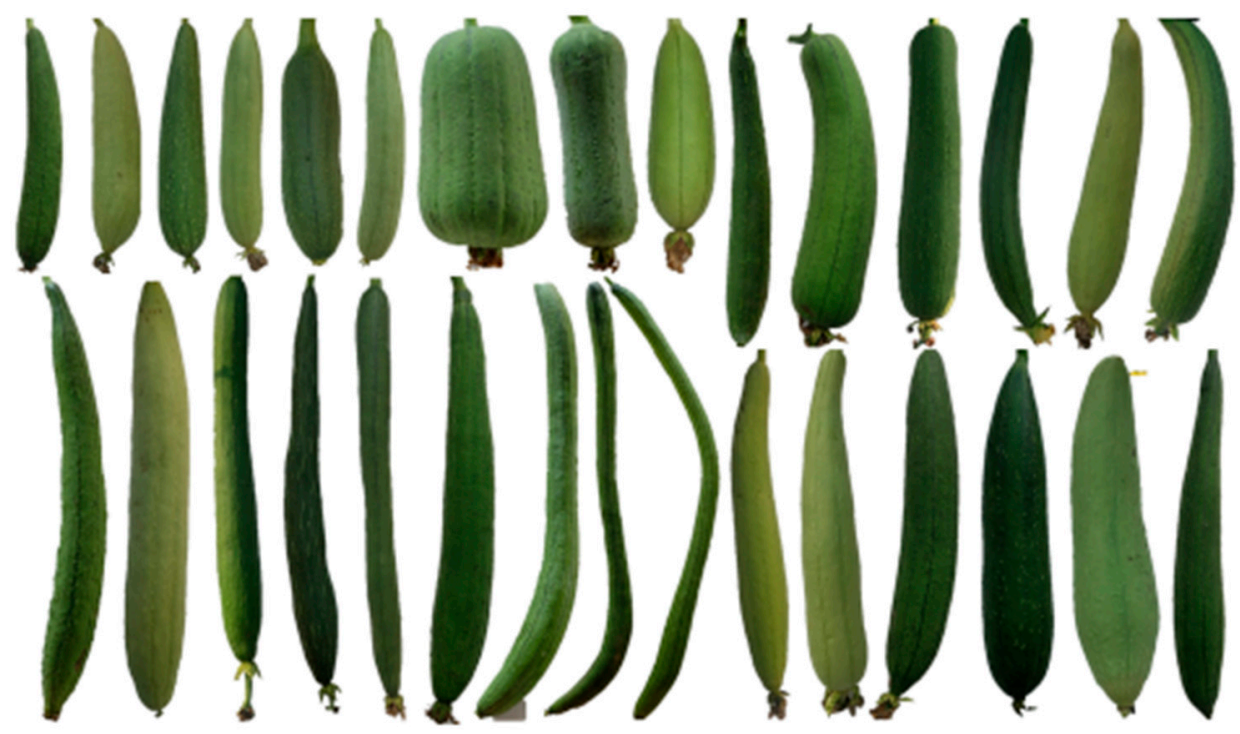

Figure 4. Fruit color and length variability among sponge gourd breeding lines developed at WorldVeg.

\section{Conclusions and Outlook}

Global plant breeding projects under public-private partnerships have focused mainly on the pre-breeding of major crops such as wheat, maize, rice, and barley or vegetables such as tomato and chili and not on the development of new cultivars of minor crops of the Cucurbitaceae family [44-46]. Cucurbits are a diverse family of vegetable crops that are of great economic importance to smallholder farmers and consumers, particularly in Asia. The World Vegetable Center has been able to collect a diverse germplasm collection from different parts of the world and has made this available to public and private breeding programs globally. Breeding efforts have focused on four species: bitter gourd, tropical pumpkin, ridge gourd, and sponge gourd. These cucurbits are of great interest to private seed companies in Asia, which have partnered with the WorldVeg. This partnership has enabled the pool of genetic resources used in commercial breeding programs to be widened and the introduction of new traits such as multiple virus resistance, powdery mildew resistance, and high yield. Much work remains to be done to introduce new traits that will be of increasing importance, such as dwarf vines, enhanced nutrient density, longer shelf life, extended fruit harvest, parthenocarpic gourds, bitter gourd gynoecious lines of different market segments, and tolerance to abiotic stresses. Genomic tools 
have improved the breeding efficiency of major cucurbit crops, and transgenic and genome-edited plants have been produced [47,48]. The availability of whole genome sequences of C. moschata [49], M. charantia [50], and L. cylindrica [51] is stimulating molecular breeding approaches in these crops. Several markers putatively associated with resistance to ZYMV in pumpkin and CPM in bitter gourd have been proposed and are being validated.

There is much potential to expand commercial and home garden production of cucurbits in Africa and South and Central America as these crops can contribute to diversifying agricultural production systems and improving global food and nutrition security in these regions. It is important that governments, donors, and research and development organizations recognize the considerable potential of cucurbits.

Author Contributions: Conceptualization, N.P.S.D.; first draft preparation, N.P.S.D.; writing-review \& editing, N.P.S.D., S.L., S.S., S.P., A.M., A.K., K.K.Y., G.H., P.H., R.S. and P.S.; Funding acquisition from seed companies, N.P.S.D. All authors have read and agreed to the published version of the manuscript.

Funding: This research received external funding from twenty-five collaborative seed companies (World Vegetable Center project numbers: $10000274,10000292,10000365)$. Funding for this research was also provided by strategic long-term donors to the World Vegetable Center: Taiwan, UK aid from the UK government, United States Agency for International Development (USAID), Australian Centre for International Agricultural Research (ACIAR), Germany, Thailand, Philippines, Korea, and Japan. We thank Professor Graham Jellis for editing the manuscript.

Conflicts of Interest: The authors declare no conflict of interest.

\section{References}

1. Schaefer, H.; Renner, S.S. Phylogenetic relationships in the order Cucurbitales and a new classification of the gourd family (Cucurbitaceae). Taxon 2011, 60, 122-138. [CrossRef]

2. FAOSTAT Database on Production. FAO Statistics Division, Food and Agriculture Organization of the United Nations, Rome. 2019. Available online: http://www.fao.org/faostat/en/\#data (accessed on 14 August 2019).

3. Dhillon, N.P.S.; Sanguansil, S.; Singh, S.P.; Masud, M.A.T.; Kumar, P.; Bharathi, L.K.; Yetisir, H.; Huang, R.; Canh, D.X.; McCreight, J.D. Gourds: Bitter, bottle, wax, snake, sponge and ridge. In Genetics and Genomics of Cucurbitaceae; Grumet, R., Katzir, N., Garcia-Mas, J., Eds.; Springer: Gewerbestrasse, Switzerland, 2017; pp. 155-172.

4. Dhillon, N.P.S.; Sanguansil, S.; Schafleitner, R.; Wang, Y.-W.; McCreight, J.D. Diversity among a wide collection of bitter gourd landraces and their genetic relationships with commercial hybrid cultivars. J. Am. Soc. Hortic. Sci. 2016, 141, 475-484. [CrossRef]

5. Zheng, Y.; Wu, S.; Bai, Y.; Sun, H.; Jiao, C.; Guo, S.; Zhao, K.; Blanca, J.; Zhang, Z.; Huang, S.; et al. Cucurbit Genomics Database (CuGenDB): A central portal for comparative and functional genomics of cucurbit crops. Nucleic Acids Res. 2019, 47, D1128-D1136. [CrossRef] [PubMed]

6. World Vegetable Center. International Vegetable Breeding: A Strategy to Create Development Impact at Scale; Publication No. 19-838; World Vegetable Center: Shanhua, Taiwan, 2019.

7. The US Department of Agriculture (USDA). National Nutrient Database for Standard Reference. Available online: http://www.ars.usda.gov/Services/docs.htm?docid=8964 (accessed on 1 March 2020).

8. APSA-WorldVeg. Vegetable Breeding Consortium. Available online: https://avrdc.org/apsa-worldvegvegetable-breeding-consortium/ (accessed on 1 March 2020).

9. McCreight, J.D.; Staub, J.E.; Wehner, T.C.; Dhillon, N.P.S. Gone global: Familiar and exotic cucurbits have Asian origins. HortScience 2013, 48, 1078-1089. [CrossRef]

10. Chawda, V.; (VNR Seeds Private Limited, Raipur, Chhattisgarh, India). Personal communication, 2020.

11. Morgan, W.; Midmore, D. Bitter Melon in Australia; Publication No. 02/134; Rural Industries Research and Development Corporation: Rockhampton, Australia, 2002; 29p.

12. Dhillon, N.P.S.; Lin, C.C.; Sun, Z.; Hanson, P.M.; Dolores, R.L.; Habicht, S.D.; Yang, R. Varietal and harvesting stage variation in the content of carotenoids, ascorbic acid and tocopherols in the fruit of bitter gourd (Momordica charantia L.). Plant Genet. Resour. 2017, 15, 248-259. [CrossRef]

13. World Health Organization. Global Report on Diabetes. 2016. Available online: https://www.who.int/ diabetes/global-report/en/ (accessed on 1 March 2020). 
14. Amorthaveni, M.; Premakumari, S.; Gomathi, K.; Yang, R. Hypoglycemic effect of bitter gourd (Momordica charantia L.) among pre diabetics in India. Indian J. Nutr. Diabet. 2018, 55, 44-63. [CrossRef]

15. Krawinkel, M.B.; Ludwig, C.; Swai, M.E.; Yang, R.; Chun, K.P.; Habicht, S.D. Bitter gourd reduces elevated fasting plasma glucose levels in an intervention study among prediabetics in Tanzania. J. Ehnopharmacol. 2018, 216, 1-7. [CrossRef]

16. Keinath, A.P.; DuBose, B. Evaluation of fungicides for prevention and management of powdery mildew on watermelon. Crop Prot. 2004, 23, 35-42. [CrossRef]

17. Dhillon, N.P.S.; Sanguansil, S.; Srimat, S.; Schafleitner, R.; Manjunath, B.; Agarwal, P.; Xiang, Q.; Masud, M.A.T.; Myint, T.; Hanh, N.T.; et al. Cucurbit powdery mildew-resistant bitter gourd breeding lines reveal four races of Podosphaera xanthii in Asia. HortScience 2018, 48, 1078-1089. [CrossRef]

18. Dhillon, N.P.S.; Sanguansil, S.; Srimat, S.; Laenoi, S.; Schafleitner, R.; Pitrat, M.; McCreight, J.D. Inheritance of resistance to cucurbit powdery mildew in bitter gourd. HortScience 2019, 54, 1013-1016. [CrossRef]

19. Yadav, K.K.; (Noble Seeds Private Limited, Bangalore, Karnataka, India). Personal communication, 2020.

20. Nagendran, K.; Mohankumar, S.; Aravintharaj, R.; Balaji, C.G.; Manoranjitham, S.K.; Singh, A.K.; Rai, A.B.; Singh, B.; Karthikeyan, G. The occurrence and distribution of major viruses infecting cucurbits in Tamil Nadu state, India. Crop Prot. 2017, 99, 10-16. [CrossRef]

21. Rosen, R.; Kanakala, S.; Kliot, A.; Pakkianathan, B.C.; Farich, B.A.; Santana-Magal, N.; Elimelech, M.; Kontsedalov, S.; Lebedev, G.; Cilia, M.; et al. Persistent, circulative transmission of begomoviruses by whitefly vectors. Curr. Opin. Virol. 2015, 15, 1-8. [CrossRef] [PubMed]

22. Yadav, K.K.; Hegde, G.; Agarwal, P.; Chawda, V.; Kenyon, L.; Dhillon, N.P.S. Multi-location preliminary field screening of World Vegetable Center bitter gourd breeding lines for reaction to Tomato leaf curl new Delhi virus in selected hotspots in India. Acta Hortic. 2019, 1257, 9-14. [CrossRef]

23. Hegde, G.; (Noble Seeds Private Limited, Bangalore, Karnataka, India). Personal communication, 2020.

24. Anil, M.; (Acsen HyVeg Private Limited, Bangalore, Karnataka, India). Personal communication, 2020.

25. Kataria, S.; (Kumar Bioseeds \& Agro Products LLP, Pune, India). Personal communication, 2020.

26. Puttapa, P.; (Sakata Seeds India Private Limited, Bangalore, Karnataka, India). Personal communication, 2020.

27. Deshmukh, S.; (Ajeet Seeds Private Limited, Aurangabad, Maharashtra, India). Personal communication, 2020.

28. Varma, R.; (Kaveri Seeds Private Limited, Hyderabad, India). Personal communication, 2020.

29. Kumar, V.; (I \& B Seeds, Bangalore, Karnataka, India); Murali, K.; (Acsen HyVeg Private Limited, Bangalore, Karnataka, India); Acharya, S.; (JK Agri Genetics Limited, Hyderabad, India); Chauhan, K.M.; (Kaveri Seeds Private Limited, Hyderabad, India); Kumar, M.; (Nuziveedu Seeds Limited, Hyderabad, Telangana, India); Naik, S.; (Ankur Seeds Private Limited, Nagpur, Maharashtra, India); Deshmukh, P.; (Sungro Seeds Private Limited, Mumbai, Maharashtra, India); Rathi, S.; (Sattva Seeds Private Limited, Raipur, Chhattisgarh, India); Vamanrao, P.; (HM Clause India, Bangalore, Karnataka, India;); Venus-Bautista, M.; (East-West Seed, Manila, Philippines). Personal communication, 2020.

30. Kumar, P.; (Enza Zaden India Private Limited, Pune, Maharashtra, India). Personal communication, 2020.

31. Ahamed, K.U.; Akhter, B.; Islam, M.R.; Ara, N.; Humauan, M.R. An assessment of morphology and yield characteristics of pumpkin (Cucurbita moschata) genotypes in northern Bangladesh. Trop. Agric. Res. Ext. 2011, 14, 7-11. [CrossRef]

32. World Health Organization. Micronutrient Deficiencies. Available online: https://www.who.int/nutrition/ topics/vad/en/ (accessed on 1 March 2020).

33. Nokham, N.; Boonmala, N.; Arsakit, K.; Yusuk, P.; Dhillon, N.P.S. Performance of pumpkin lines bred by World Vegetable Center in different highland areas of Thailand during the winter season. In Proceedings of the Cucurbitaceae 2018, Davis, CA, USA, 12-15 November 2018; p. 114.

34. Chan, Y.L.; Lee, L.M.; Shih, S.L.; Kuo, F.H.; Kenyon, L. Survey of virus diseases affecting squash (Cucurbita moschata) in Taiwan. Acta Hortic. 2019, 1257, 23-28. [CrossRef]

35. Ibada, J.D.; Laing, M.D.; Gubba, A. Incidence and phylogeny of viruses infecting cucurbit crops in KwaZulu-Natal, Republic of South Africa. Crop Prot. 2015, 75, 46-54.

36. Desbiez, C.; Millot, M.D.; Wipf-Scheibel, C.; Blancard, D.; Chesneau, T.; Lecoq, H. First report of Pepo aphid-borne yellows virus in cucurbits in Tanzania and Mayotte. New Dis. Rep. 2016, 33, 20. [CrossRef]

37. Srimat, S.; Laenoi, S.; Suk-Woo, J.; Dhillon, N.P.S. Screening of pumpkin breeding populations against potyviruses and geminiviruses, and key fruit traits. Acta Hortic. 2020, (in press). 
38. Dhillon, N.P.S.; Sanguansil, S.; Srimat, S.; Cheng, H.C.; Lin, C.C.; Srinivasan, R.; Kenyon, L.; Schafleitner, R.; Yang, R.; Hanson, P. Status of cucurbit breeding at AVRDC-The World Vegetable Center. In Proceedings of the Cucurbitaceae 2016, XIth EUCARPIA Meeting on Cucurbit Genetics and Breeding, Warsaw, Poland, 24-28 July 2016; Kozik, E.U., Paris, H.S., Eds.; Cucurbitaceae 2016 Organizing Committee: Skierniewice, Poland, 2016; pp. 21-25.

39. Hsin-chun, C.; (World Vegetable Center, Shannhua, Taiwan). Personal communication, 2020.

40. Whitaker, T.W.; Davis, G.N. Cucurbits. In Botany, Cultivation, and Utilization; Interscience Publishers, Inc.: New York, NY, USA, 1962; 250p.

41. Masud, M.A.T.; (Bangladesh Agricultural Research Institute, Gazipur, Bangladesh). Personal communication, 2020.

42. Lin, M.L. (World Vegetable Center, Shannhua, Taiwan). Personal communication, 2020.

43. Dhillon, N.P.S.; Masud, M.A.T.; Pruangwitayakun, S.; Natheung, M.; Lertlam, S.; Jarret, R.L. Evaluation of loofah lines for resistance to tomato leaf curl New Delhi virus and downy mildew, as well as key horticultural traits. Agriculture 2020, 10, 298. [CrossRef]

44. Lusser, M. Proceedings of Workshop on Public-Private Partnerships in Plant Breeding; Publications Office of the European Union: Luxembourg, 2014; 64p.

45. Van Berloo, R.; Van Heusden, S.; Bovy, A.; Meijer-Dekens, F.; Lindhout, P.; Van Eeuwijk, F. Genetic research in a public-private research consortium: Prospects for indirect use of Elite breeding germplasm in academic research. Euphytica 2008, 161, 293-300. [CrossRef]

46. Ashrafi, H.; Hill, T.; Stoffel, K.; Kozik, A.; Yao, J.; Chin-Wo, S.R.; Van Deynze, A. De novo assembly of the pepper transcriptome (Capsicum annuum): A benchmark for in silico discovery of SNPs, SSRs and candidate genes. BMC Genom. 2012, 13, 571. [CrossRef] [PubMed]

47. Feng, S.; Zhang, J.; Mu, Z.; Wang, Y.; Wen, C.; Wu, T.; Yu, C.; Li, Z.; Wang, H. Recent progress on the molecular breeding of Cucumis sativus L. in China. Theor. Appl. Genet. 2020, 133, 1777-1790. [CrossRef] [PubMed]

48. Ram, C.; Berwal, M.K.; Gora, J.S.; Kumar, R.; Haldhar, S.M.; Gurjar, K.; Singh, D. Genomic and biotechnological interventions for crop improvement in cucurbitaceous crops: A review. J. Agric. Ecol. 2019, 7, 1-15.

49. Sun, H.; Wu, S.; Zhang, G.; Jiao, C.; Guo, S.; Ren, Y.; Zhang, J.; Zhang, H.; Gong, G.; Jia, Z.; et al. Karyotype stability and unbiased fractionation in the paleo-allotetraploid Cucurbita genomes. Mol. Plant 2017, 10, 1293-1306. [CrossRef] [PubMed]

50. Matsumura, H.; Hsiao, M.C.; Toyoda, A.; Taniai, N.; Tarora, K.; Urasaki, N.; Anand, S.S.; Dhillon, N.P.S.; Schafleitner, R.; Lee, C.R. Long-read bitter gourd (Momordica charantia) genome and the genomic architecture of nonclassic domestication. Proc. Natl. Acad. Sci. USA 2020, 117, 14543-14551. [CrossRef]

51. Zhang, T.; Ren, X.; Zhang, Z.; Ming, Y.; Yang, Z.; Hu, J.; Li, S.; Wang, Y.; Sun, S.; Sun, K.; et al. Long-read sequencing and de novo assembly of the Luffa cylindrica (L.) Roem. genome. Mol. Ecol. Resour. 2020, 20, 511-519. [CrossRef]

(C) 2020 by the authors. Licensee MDPI, Basel, Switzerland. This article is an open access article distributed under the terms and conditions of the Creative Commons Attribution (CC BY) license (http://creativecommons.org/licenses/by/4.0/). 